Research Article/Araştırma Makalesi

\title{
The Effects of the Technology Supported Problem-Based Learning Activities on Students' Achievement in Mathematics
}

\author{
Yücel ÇETIN ${ }^{* 1}$ @Şeref MIRASYEDİĞLU2 (D) \\ ${ }^{1}$ Biruni University, Faculty of Education, İstanbul, Turkey, yucelhoca1@gmail.com \\ ${ }^{2}$ Başkent University, Faculty of Education, Ankara, Turkey, serefm@baskent.edu.tr \\ *Corresponding Author: yucelhoca1@gmail.com
}

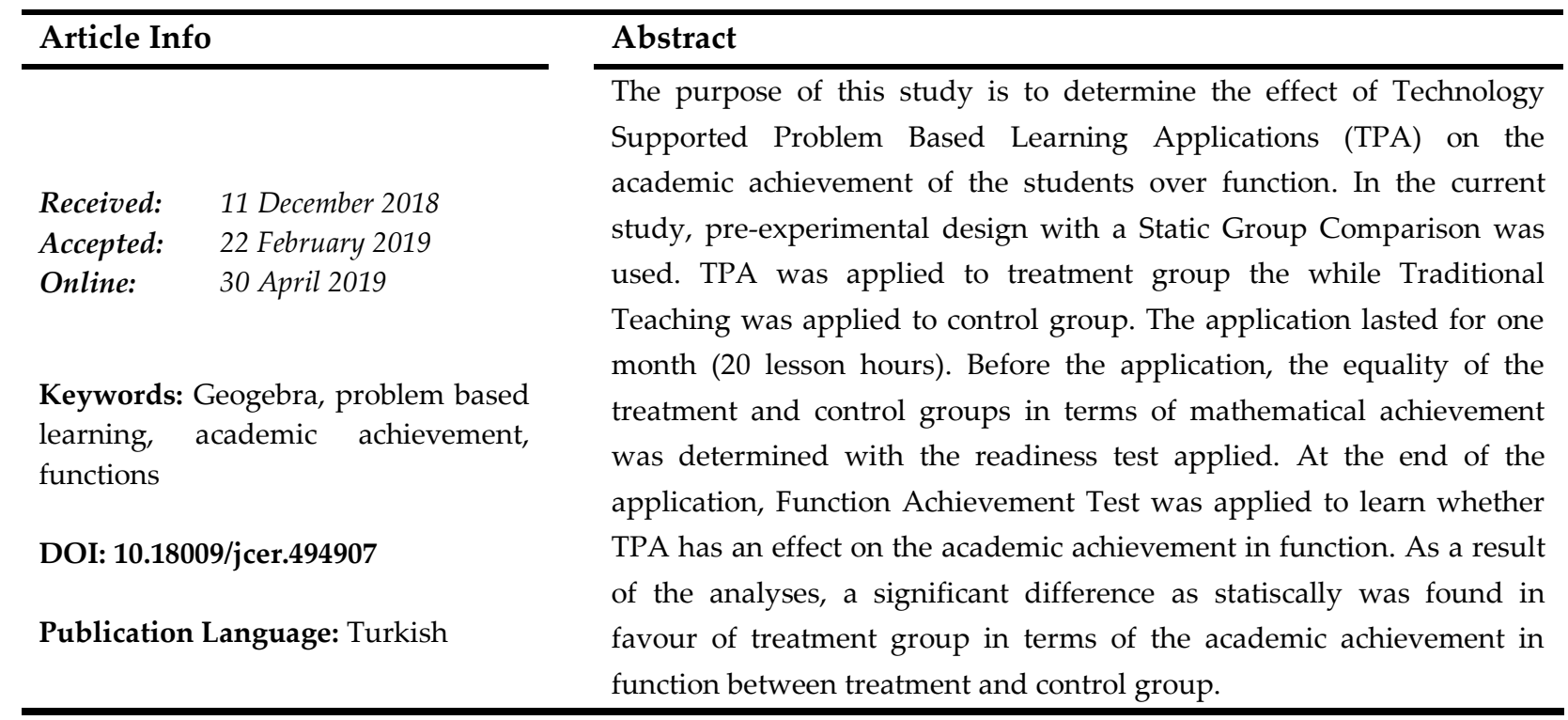

open access (a) CrossMark CC

To cite this article: Çetin, Y. \& Mirasyedioğlu, Ş. (2019). Teknoloji destekli probleme dayalı öğretim uygulamalarının matematik başarısına etkisi. Journal of Computer and Education Research, 7 (13), 13-34. DOI: $10.18009 /$ jcer.494907

\section{Teknoloji Destekli Probleme Dayalı Öğretim Uygulamalarının Matematik Başarısına Etkisi}

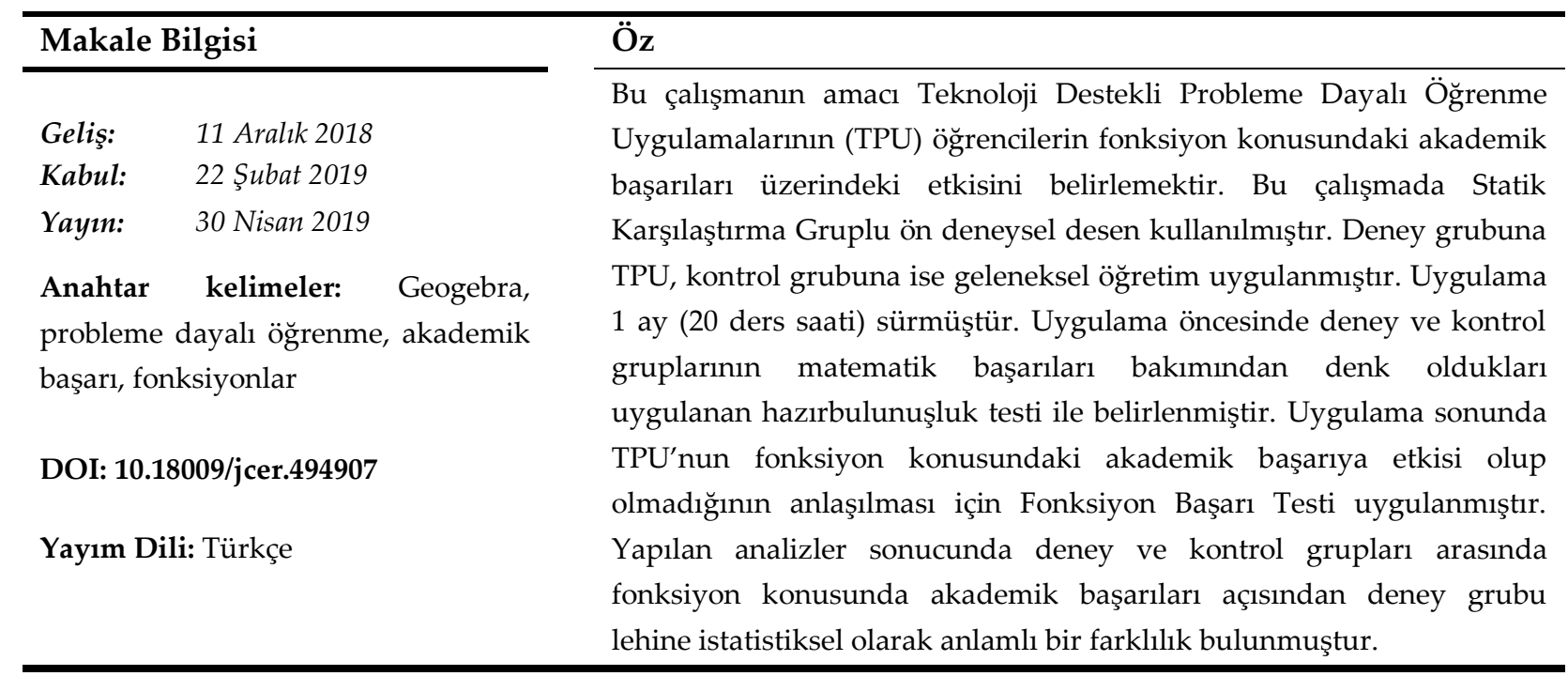




\section{Summary}

\section{The Effects of the Technology Supported Problem-Based Learning Activities on Students' Achievement in Mathematics}

\section{Introduction}

There is a need in our current time for approaches that will help to understand mathematical concepts better and saving mathematics from abstractness and making it concrete. The reason for conducting the current study is the fact that the objective of teaching the course of mathematics has not really been achieved through a meaningful and application-based approach. The other reasons for carrying out this research are the importance of the subject of function in mathematics education, necessity of helping students to remove their learning difficulties frequently encountered in functions subject, and the fact that the integration of technology with mathematics teaching has become a necessity with the introduction of technology in our life so rapidly in recent years. We think that the study of Technology Supported Problem Based Learning Applications (TPA) will make a contribution to the field in line with the needs mentioned above and be a model for teachers.

The purpose of the current study is to determine the effect of TPA, which was developed by the researcher and applied to the students of a state school in the city of Ankara, on academic achievement in the subject of function. In the current study, preexperimental design with a Static Group Comparison was used. Because of easiness in application, the research was carried out on two $9^{\text {th }}$ grade classes, with 25 in one group and 20 in the other, in a high school in the district of Cankaya where the researcher works. Twelve activities prepared by the researcher in a content where students could see the place and meaning of mathematics in daily life by using problem solving method and technology in teaching the subject of functions under the name of TPA. These activities were applied to the students in the treatment group under the guidance of the researcher. It was aimed through these activities that students would be able to acquire learning meaningfully through application and using technology. In control group, traditional instruction was used and the students stayed in passive position in teaching. The application lasted 1 month (20 lesson hours). Before the application, pilot studies and validity, reliability analyses of the 
readiness test and Function Achievement Test applied to students in the study were made. In the beginning of the study, the readiness test was applied to both groups to determine the equality of the treatment and control groups in terms of mathematical achievement. At the end of the application, Function Achievement Test (FAT) was applied to learn whether TPA has an effect on the academic achievement in function. As it was $p<0,05$ at the end of $t$ test between the FAT scores, a significant difference was found. This result shows that there was a significant difference in favour of treatment group between the academic achievement of the mathematic course of the treatment group students to whom TPA was applied and the control group students to whom traditional teaching was applied. In the analysis of FAT, Eta square was found. 0.14. This level shows that the effect is large according to Cohen (1988) criteria.

One of the reasons why TPA is effective in increasing academic achievement in mathematics is the applicability of technology in mathematics teaching; since the visuality offered by technology motivates students, interests them and helps them understand the logic of mathematical concepts. At the end of TPA application, another reason why there was an increase in the mathematical achievement of the students could be enabling active participation of the students to the course. As a matter of fact, TPA applications are not only interesting and participative for the students, but also provide better understanding of the subject, since students use their skills actively and they discover knowledge on their own. Based on the results obtained in the research, it is possible to recommend the following:

TPA could be applied in different units of general mathematics or in other fields of mathematics. In addition, teachers and pre-service teachers could be given seminars and inservice training and its effect on teachers and pre-service teachers and their views on the application could be investigated. Actually, the software of Geogebra was taught to 15.000 mathematics teachers after this study via distance education by a team in which the researcher also took part. 


\section{Giriş}

Matematik ve matematiksel düşünme, günlük hayatta büyük ve önemli bir yer kaplamasına karşın dünyanın her yerinde "zor" kabul edilmekte ve öğretiminde büyük güçlükler yaşanmaktadır (Umay,1996). Matematiği öğretmenin ve öğrenmenin zorluğu gerçekten "zor" olduğundan değil, daha ziyade ona karşı geliştirilen korku, önyargı ve günlük yaşamla bağlantısının bilinmemesinden kaynaklanmaktadır (Hawson, 1994). Matematik dersinin özellikle günlük hayatla ilişkisinin kurulmadan teorik bir biçimde yapılması ve ölçme değerlendirmede klasik yöntemlerin kullanılması matematik dersinde öğrenci başarısının istenen seviyeye erişmesini engellemektedir. Bununla birlikte, matematiksel bilgilerin verilmesinin yanı sıra onun iyi öğretilmesinin de önemine değinen Steedman (1991), matematiği öğretme yönteminin başarılı bir şekilde gerçekleştirilmesinin yaşayarak, uygulayarak öğrenmeden geçtiğini ifade etmektedir. Hoyles ve Noss (1992) gibi birçok araştırmacı bilgilerin doğrudan verilmesi yerine öğrencilerin çıkarımlar yaparak, kavramları kendi zihinlerinde yapılandırmaları ve kendi ifadeleriyle belirtmelerinin onları ezbercilikten kurtaracağı düşüncesini savunmuşlardır. Hoyles ve Noss (1992) pedagoji ile matematiksel mikro işlem dünyasındaki öğrenci davranışları arasındaki ilişkiyi incelediği “A Pedagogy for Mathematical Microworlds" isimli çalışmasında bu fikri olumlu yönde desteklemiştir. Bu yüzden öğrencilerin matematiksel kavramları daha iyi anlamasına yardımcı olacak ve matematik dersini soyut olmaktan kurtarıp somutlaştıracak yaklaşımlara ihtiyaç vardır. Bu yaklaşımlardan biri de probleme dayalı öğrenme yöntemidir. Probleme Dayalı Öğrenme (PDÖ) yöntemi uygulayarak ve yaşayarak öğrenme esasına dayalı, üst düzey düşünme becerilerine sahip bireyleri yetiştirmeye elverişli bir yapıya sahip, öğrenmeyi öğreten, bilgiyi farklı durumlara uyarlama becerisi kazandıran bir öğretim yöntemidir. Günhan ve Başer (2009), PDÖ'nün yaşam boyu öğrenmeye dayandığını öğrencilerin problem çözme, üst düzey düşünme becerilerini geliştirmelerini sağladığını belirtmiştir. Bununla birlikte Usta ve Mirasyedioğlu (2017) yaptıkları çalışmanın sonucunda PDÖ ile öğrenme sürecinde öğrencilerin birbirleri ile oluşturdukları çözümleri grupça tartışmalarının, probleme farklı çözüm yolları önermelerinin ve araştırmaları sonucunda en iyi çözüme karar vererek sınıfça tartışmaları öğrencilerin düşünme becerilerinin gelişmesine katkı sağladığını belirlemişlerdir. 
Torp ve Sage (1998), PDÖ’nün öğrencilerin daha önce öğrenmedikleri bir konuda açık uçlu kurgulanan gerçek hayat problemlerinin esas alınarak bu problemlerin çözümü etrafında organize edilen ve öğrencilerin uygulayarak ve yaşayarak öğrenmelerini sağlayan öğrenme deneyimleri üzerine kurulu bir yöntem olduğunu belirtmektedirler. Hmeleo-Silver (2004), PDÖ'nün hedeflerinin öğrenciye kendi bilgi tabanını kullandırarak bilgiyi yapılandırması için yardımcı olmak, günümüzde ihtiyaç duyulan kritik düşünme, çıkarım ve genelleme yapma gibi üst düzey düşünme becerilerini geliştirmek olduğunu ifade etmiştir. Ayrıca, kendi kendine öğrenme yeteneğini ve hayat boyu öğrenme becerisini geliştirmek ve öğrencileri kendine güvenen, motive edilmiş bireyler haline getirmek olduğunu vurgulamıştır. Bu bağlamda Ali, Hukamdad, Akhter ve Khan (2010), PDÖ'nün kullanıldığı sınıflarda öğrencilerin kendi öğrenme süreçlerinde daha fazla sorumluluk aldığını ve yaşam boyu öğrenen bireyler haline geldiklerini ifade etmiştir.

Matematik eğitim bilimcilerinin görüş ve kanaatleri matematik dersinin anlamlı bir içerikle uygulamaya dönük bir yaklaşımla öğretilmesi gerektiği doğrultusundadır. Örneğin, Haladayna (1997) öğrencilerin çalıştığı şeyin hayattaki yerini gördükleri anlamlı bir içerikle öğrenmeleri gerektiğini savunmuştur. Ayrıca Milli Eğitim Bakanlığı (MEB) (2018) üst bilişsel becerilerin kullanımına yönlendiren, anlamlı ve kalıcı öğrenmeyi sağlayan, sağlam ve önceki öğrenmelerle ilişkilendirilmiş, diğer disiplinlerle ve günlük hayatla değerler, beceriler ve yetkinlikler çevresinde bütünleşmiş bir öğretimi öngörmüştür. Bununla birlikte, Baysal (2003) eğitim ortamının öğrencilerin ders konuları ile düşünme becerileri arasında ilişki kurduğu, ders sürecinde düşünme yöntemlerini kullandığı aktif ve dinamik bir öğrenme ortamı olması gerektiği halde, Türk eğitim sisteminde hâlihazırda yaşanan en önemli sorunun ezbere eğitim olduğu, öğrenilen bilgilerin günlük hayata aktarılmadığını ve sadece sınavlarda gerektiği zaman kullanılan bilgiler olarak kaldığını ifade etmiştir. Buna paralel olarak Soylu (2009), yaptığı araştırmanın sonucunda öğrencilerin çoğunun matematik dersinde düz anlatım, tanımlar, kurallar ve soru-cevap yöntem ve tekniklerinde kendilerini yeterli veya kısmen yeterli olarak görürken, yapılandırmacı yaklaşıma dayalı olan buluş yoluyla öğrenme stratejisi, işbirlikli öğrenme ve problem çözme gibi yöntem ve tekniklerde ise, kendilerini yetersiz gördüklerini tespit etmiştir. Bu ifadeler matematik dersinin anlamlı ve uygulamaya dönük bir yaklaşımla işlenmesi hedefinin uygulamaya tam anlamıyla geçirilemediğini teyit etmektedir. Bu bağlamda, bu çalışmanın bu ihtiyacı ve eksikliği gidermede bir örnek teşkil ederek alana katkı sağlaması hedeflenmektedir. 
$\mathrm{Bu}$ çalışmanın yapılmasının diğer bir önemli sebebi fonksiyon konusunun matematik öğretimi içindeki önemi ve öğrencilerin bu konuyu öğrenmede karşılaştıkları güçlüklerinin giderilerek öğrencilerin bu konudaki akademik başarılarının artırılmasına yardımcı olmaktır. Nitekim Kutluca ve Baki (2013) fonksiyonlar ve grafiklerinin matematiği anlamada çok önemli bir rol oynamakta olduğunu ifade etmişlerdir. Diğer taraftan Kabael (2010), matematiğin temel taşlarından biri olan fonksiyon kavramının, matematik eğitimcilerinin alana veya alan yazına kazandırdıkları çalışmalar ile üzerinde önemle durdukları bir kavram olmasına karşın, öğrencilerin çoğunun birçok öğrenme zorluğu yaşadıkları ve kavram yanılgılarına düştükleri bir konu olmaktan çıkamadığını ifade etmiştir.

Cansız, Küçük ve İşleyen (2011), cebir ve analiz konuları içerisinde yer alan fonksiyonun matematiğin en önemli konularından biri olduğunu, matematik öğretiminde yapılan çalışmaların genellikle fonksiyon konusunun öğretimi ve öğreniminde karşılaşılan güçlükler ve bu güçlüklerin sebepleri üzerine odaklanıldığını belirtmişlerdir. Hâlbuki bu güçlüklerin giderilmesine yönelik çalışmalar yeterli olmadığından yıllardır fonksiyon konusundaki öğrenme ve öğretme güçlüklerinin devam ettiğini vurgulamışlardır. Nitekim Malahlela (2017) öğrenme güçlüklerini gidermeye yönelik hazırlanan uygulamaların kullanılmasının fonksiyonların daha iyi öğrenilmesine yardımcı olacağını ifade etmiştir.

$\mathrm{Bu}$ çalışmanın yapılmasındaki diğer önemli bir sebep ise son yıllarda teknolojinin süratli bir şekilde gelişerek hayatımızın her alanına girmesi nedeniyle teknolojinin eğitime entegrasyonunu bir gereklilik haline getirmesi olmuştur. National Council of Teachers of Mathematics (NCTM) (2001) teknolojiyi matematik öğretiminde gerekli olan ve öğrenmeyi zenginleştirici bir unsur olarak ifade etmiştir. Hannafin, Little ve Burruss (2001) teknoloji kullanımının öğrencilerin derse aktif katılımını, motivasyonlarını artırdığını ve öğrencilerin matematiksel ilişkilendirme becerilerini geliştirmelerine yardımcı olduğu sonucuna erişmişlerdir. Bununla birlikte Aydın, Laçin ve Keskin (2018) öğretmen görüşlerini incelediği çalışmasında öğretmenlerin teknolojiden yeterince yararlanamadığını, bu teknolojilerin öğretmenler tarafından daha aktif olarak kullanılmasının sağlanması durumunda öğrenci başarısının da artabileceğini vurgulamışlardır. Ayrıca, Zengin ve Tatar (2015), Geogebra uygulamalarıyla destekli öğrenme modelinin aktif öğrenme ortamı sağlayarak öğrencilerin duyuşsal becerilerini geliştirmeye katkıda bulunduğunu belirlemiştir. Bunun yanı sıra, Fies (2007) ortaöğretim matematik ve fen sınıflarında teknolojinin kullanımı hakkında yaptığı çalışmanın sonucunda öğrencilerin motivasyonlarında, derse aktif katılımlarında artış 
olduğunu, muhakemelerinin, çıkarım yapma becerilerinin geliştiğini belirlemiş ve teknolojinin öğrenme üzerindeki etkisinin tam olarak anlaşılmasını sağlayacak çalışmalara ihtiyaç olduğunu tespit etmiştir. Bu bağlamda, matematik öğretiminde yapılan bu çalışmanın yukarıda belirttiğimiz ihtiyaçlar doğrultusunda alana katkıda bulunabileceği ve öğretmenler için bir model olabileceği düşünülmektedir. Bunların yanı sıra, bu araştırmada dinamik matematik yazılımlarından Geogebra'nın tercih edilmesinin belli başlı üç sebebi vardır. Bunlar; kullanışlılık, ücretsiz erişim ve fonksiyon konusunun kolaylıkla uygulanabilmesidir.

\section{Araştırmanın Amacı}

$\mathrm{Bu}$ çalışmada araştırmacı tarafından geliştirilen Teknoloji Destekli Probleme Dayalı Öğrenme Uygulamaları (TPU) bir devlet lisesinde öğrenim gören 9.sınıf öğrencileri üzerinde uygulanmıştır. Bu çalışmanın amacı TPU' nun öğrencilerin fonksiyon konusundaki akademik başarıları üzerindeki etkisi olup olmadığını belirlemektir. Bu amaca ulaşmak için de şu soruya cevap aranmıştır. Deney grubu öğrencileri ile kontrol grubu öğrencilerinin fonksiyon konusundaki başarıları arasında istatistiksel olarak anlamlı bir farklılık var mıdır?

\section{Yöntem}

$\mathrm{Bu}$ araştırmada TPU 'nun öğrencilerin akademik başarılarına etkisinin olup olmadığını belirlenmesi için uygulama kolaylığı açısından ve okulda 9.sınıf öğrencilerini rastgele atamak mümkün olmadığından nicel araştırma yöntemlerinden statik karşılaştırma gruplu ön deneysel araştırma deseni kullanılmıştır. Bu araştırma deseni özel bir işlemin sonuç üzerinde etkisinin olup olmadığını belirlemeye çalışır. Araştırmacı bu işlemi yaparken gruplardan birine özel müdahalede bulunurken diğer gruba bulunmaz ve çalışma sonunda her iki gruba uygulanan son testin puanları iki grup arasındaki farklılığı ölçmek için değerlendirilir (Gay \& Airasian, 2000). Bu desenin deneysel desenden en önemli farkı iç geçerliğin önemli unsuru olan rastgele oluşturulan kontrol grubunun olmamasıdır. Statik karşılaştırma gruplu ön deneysel araştırma deseninde araştırmacı mevcut olan iki grubu deney ve kontrol grubu olarak kullanır. Deneysel işlem uygulanmayan kontrol grubu, deney grubuna yapılan uygulamanın etkisini ortaya koymak amacına hizmet eder (Gay \& Airasian, 2000). Bu araştırma deseninin iç geçerlik tehdidini gidermek amacıyla grupların matematik başarısı açısından denk olup olmadıklarını belirlemek üzere matematik dersi Hazır Bulunuşluk Testi (HBT) çalışma öncesinde her iki gruba da uygulanmıştır. Uygulama 
sonunda TPU' nun akademik başarıya etkisi olup olmadığını belirlemek için her iki gruba da son test olarak Fonksiyon Başarı Testi (FBT) uygulanmıştır. Tablo 1' de bu desenin görsel modeli verilmiştir. X: Deney grubuna uygulanan TPU' yu, O: her iki gruba fonksiyon konusunun öğretimi sonrasında uygulanan FBT’yi temsil etmektedir.

Tablo 1. Araştırmanın deneysel deseni

\begin{tabular}{lcc}
\hline Sinıflar & Uygulanan Öğretim & Uygulanan Başarı Testi \\
\hline Deney Grubu & $\mathrm{X}$ & $\mathrm{O}$ \\
Kontrol Grubu & & $\mathrm{O}$ \\
\hline
\end{tabular}

(Creswell, 2014)

Deney grubuna TPU, kontrol grubuna ise geleneksel öğretim (GÖ) uygulanmıştır. Çalışmada bağımsız değişken öğretim yöntemi, bağımlı değişken ise öğrencilerin matematik dersi fonksiyon konusundaki başarılarıdır.

\section{Araştırma Süreci}

Araştırmada yürürlüğe 2013 yılında girmiş olan 9.sınıf 'Fonksiyonlar' konusunun kazanımlarının öngördüğü konular doğrultusunda 2013-2014 öğretim döneminde uygulama yapılmıştır. Araştırmacı tarafından deney grubu öğrencilerine günlük hayat uygulamalarına dayalı, grup çalışması ve teknolojiyi kullanacakları etkinlikler uygulanmıştır. Kullanılan etkinliklerin uygunluğu uzman görüşleri ve yönlendirmeleri ile sağlanmıştır. Kontrol grubuna ise yine araştırmacı tarafından geleneksel öğretim uygulanmıştır. Kontrol grubunda sadece kazanımların öngördüğü konular esas alınmıştır. Kazanımların öngördüğü geleneksel öğretimin haricindeki diğer amaç ve yöntemler dikkate alınmamıştır. Dolayısıyla, kontrol grubunda geleneksel öğretime uygun olarak öğrenciler ders işleyişinde pasif konumda bulunmuşlardır. Araştırmada her iki grubun matematik derslerine aynı öğretmenin girmesiyle öğretmen farklılığı etkenine meydan verilmemiştir.

\section{Deney Grubu Ders İşlenişi}

Fonksiyonlar konusunun öğretiminde TPU adı altında problem çözme ve teknolojiyi kullanarak matematiğin günlük hayattaki yerini ve anlamını görebilecekleri bir içerikte araştırmacı tarafından hazırlanan 12 etkinlik deney grubu öğrencilerine araştırmacı rehberliğinde uygulanmıştır. TPU' da kullanılan etkinliklerin isimleri aşağıda verilmiştir.

Fonksiyon Kavramı (Bulutların Yerden Yüksekliği) Etkinliği; Fonksiyon Kavramı (Doğalgaz Sayac1) Etkinliği; Fonksiyon Kavramı (Su Faturası) Etkinliği; Doğrusal Fonksiyon 
(Taksimetre) Etkinliği; Doğrusal Fonksiyon (Cep Telefonu) Etkinliği; Eğim Kavramı Etkinliği; Düşey Doğru Testi Etkinliği; Doğrusal Fonksiyon Grafiği Etkinliği; Tanım ve Değer Kümesi Etkinliği; Parçalı Fonksiyon Etkinliği; Bire bir Fonksiyon Etkinliği; Fonksiyon Grafiği Etkinliğidir. Bu etkinliklerden Doğrusal Fonksiyon (Cep Telefonu) Etkinliği isimli etkinlik EK kısmında görülebilir.

Bu etkinliklerde öğrenciler için uygun problemlere dönüştürülen gerçek yaşam durumlarından örnekler verilmiştir. TPU etkinliklerinin uygulanma sürecinde öğrencilerden, hem grup hem de sınıf tartışmaları yoluyla matematiksel bir sonuca varmaları istenmiştir. Öğrencilerin matematik dersinde matematik kavramları üzerinde konuşabilmelerinin sağlanması, etkinliklerin geliştirilmesi sürecinde göz önüne alınan hususlardan bir tanesidir. Öğrencilerin etkinlik ve problem çözme sürecine aktif katılımlarını ifade eden, fikirlerini söyleyebilmeleri ve tartışmalara dâhil olmalarını ima eden konuşmalar, matematiğin kavramsal öğrenilmesine de yardımcı olmaktadır (NCTM, 2013). Öğrenciler bu süreçte çıkarımlar yapmalı, konuşmalı, arkadaşlarının fikirlerine itiraz etmeli, katılmalı, kendini fikirlerini savunmalı veya düzeltmelidir (Leinhardt, ve di $\breve{g} ., 1990$ ).

TPU etkinliklerinin uygulandığı deney grubunda 4 'ü 4 kişilik,3'ü 3 kişilik olmak üzere 7 grup oluşturulmuş ve gruplar öğrenciler tarafından isimlendirilmiştir. Deney grubu öğrencilerine uygulanacak yeni yöntem ve uygulamada kullanacakları Geogebra yazılımı hakkında 2 saatlik eğitim verilmiştir. TPU etkinliklerinin uygulanması 1 aylık bir süreçte gerçekleştirilmiştir. Uygulamada öncelikle etkinlik kâğıtları gruplara dağıtılıp grup üyelerinin işbirliği yaparak öğretmenin rehberliği ve yardımıyla etkinlikleri uygulamaları sağlanmıştır. Keşfetmeye dayalı etkinliklerde soru cevap tekniği ile öğrencilerin ulaştıkları sonuçları ifade etmeleri istenmiştir. Ayrıca öğrencilerin bu sonuçlara nasıl ve ne şekilde ulaştıkları sınıf ortamında beraberce irdelenmiştir.

Deney grubunda dersin işlenişi 3 farklı ortamda ve biçimde gerçekleştirilmiştir. Birincisi sınıf içinde etkinlerin grup çalışmasıyla uygulanması, ikincisi bilgisayar laboratuvarında akıllı tahta ve dinamik matematik yazılımının kullanıldığı etkinlikler ve üçüncüsü ise sınıf dışı etkinlik ve proje hazırlama şeklinde gerçekleştirilmiştir.

Kontrol Grubu Ders İşlenişi (Geleneksel Öğretim)

$\mathrm{Bu}$ çalışmada kontrol grubuna geleneksel öğretim uygulanmıştır. Geleneksel öğretim düz anlatım, soru-cevap, tartışma gibi yöntemlerin kullanıldığı ve öğretmen merkezli bir öğretim şeklidir. Kocakülah (2006) geleneksel öğretimi öğretmen merkezli, çoğunlukla düz- 
anlatım ve soru-cevap yönteminin tercih edildiği, öğrencinin ders boyunca pasif olduğu, sınıf düzeninin tahta başındaki öğretmen ve arka arkaya sıralarda oturmuş öğrencilerin onun her yazdığını genellikle sorgulamadan not ettikleri bir biçimde olduğu öğretim süreci olarak ifade etmiştir. Kontrol grubunda öğretmen akıllı tahtada konu ile ilgili kavramları ve kuralları kısaca anlatıp yazdırdıktan sonra konuyla ilgili soruların çözümüne geçmiştir. Bu sorular sadece işlemsel sorular olup günlük hayatla ilişkili olmayan örneklerden oluşmuştur. Öğretmen ilk bir iki örneği akıllı tahtada kendisi çözdükten sonra birkaç örnek daha yazıp öğrencilerin çözmesi için kısa bir süre verdikten sonra sınıftan rastgele bir öğrenciyi kaldırarak sorunun çözümünü yaptırmıştır. Öğretmen sorunun çözümünü kendisi tekrar anlatmış ve öğrencilerin sorularını cevaplamıştır. Kontrol grubu ders işlenişine bir örnek EK kısminda görülebilir.

\section{Çalışma Grubu}

Araştırmada çalışma grubu olarak 9.sınıflardan biri deney biri kontrol grubu olmak üzere iki sınıf uygulama kolaylığı açısından seçkisiz olmayan örnekleme yöntemlerinden uygun örnekleme yöntemiyle araştırmacının kendi okulunda matematik derslerini yürüttüğü iki sınıf seçilmiştir. Çalışma grubu 2013-2014 eğitim öğretim yılında AnkaraÇankaya ilçesinde bulunan, sınavla öğrenci alan ve eşit ağırlık alanında eğitim veren bir devlet lisesinin 9.sınıf öğrencileridir. Biri deney (25 kişi), biri kontrol grubu (20 kişi) olmak üzere 45 kişilik bir öğrenci grubu üzerinde araştırma yapılmıştır. Deney grubunda 12 erkek $13 \mathrm{kız}$ öğrenci, kontrol grubunda ise 10 erkek 10 kız öğrenci bulunmaktadır. Çalışmada fonksiyon konusunu deney grubu Teknoloji Destekli Probleme Dayalı Öğrenme uygulamalarıyla, kontrol grubu ise Geleneksel Öğretim ile işlemiştir.

Veri Toplama Araçları

$\mathrm{Bu}$ araştırmada ölçme araçları olarak, uygulama öncesinde öğrencilerin matematik seviyelerinin denk olup olmadığını ölçmek amacıyla 'Matematik Hazır Bulunuşluk Testi', uygulamanın bitiminde deney ve kontrol grupları öğrencilerinin fonksiyon konusundaki başarıları arasında anlamlı bir farklılık olup olmadığını belirlemek amacıyla son test olarak “Fonksiyon Başarı Testi” kullanılmıştır.

\section{Hazır Bulunuşluk Testi}

Deney ve kontrol grupları öğrencilerinin akademik başarı seviyelerini uygulama öncesinde karşılaştırmak için araştırmacı tarafından 3 uzmanın görüşleri alınarak 15 sorudan oluşan bir Hazır Bulunuşluk Testi (HBT) hazırlanmıştır. Bu test, fonksiyon konusu öncesinde 
9.sınıf öğretim programına göre işlenen konuların kazanımlarına uygun olacak biçimde hazırlanmış ve test sorularında fonksiyon konusuna ön koşul teşkil eden konulara ağırlık verilmiştir.

HBT soruları ilk etapta 3 kişilik uzman grup tarafından incelenerek dil, kapsam ve psikometrik özellikleri açılarından değerlendirilmiş ve bu değerlendirmeler ışığında düzenlenmiştir. Ayrıca, HBT için deneysel çalışmadan önce Ankara ili Etimesgut ilçesindeki bir Anadolu lisesinin 9. sınıflarında okuyan 78 öğrenci üzerinde bir pilot çalışma yapılmıştır. Yapılan uygulama sonrasında testin psikometrik özelliklerini belirlemek için madde güçlüğü, madde ayırt ediciliği ve korelasyon analizleri yapılarak testin madde analizi gerçekleştirilmiştir. Analizlerde Iteman ve SPSS programları kullanılmıştır. Aşağıda yer alan Tablo 2' de çoktan seçmeli sorular için Iteman programı ile elde edilen ayırt edicilik indeksi ve Point Biserial bulguları verilmiştir. Madde ayırt ediciliğgi; testin ölçmeyi amaçladığı özelliğe yüksek düzeyde sahip olan bireylerle, düşük düzeyde sahip olan bireyleri ayırt etme gücünü gösterir. Pearson korelasyon katsayısı iki değişken arasında anlamlı ilişki olup olmadığının göstergesidir (Kalaycı, 2010).

Tablo 2. Hazır bulunuşluk testi pilot çalışma analizi-çoktan seçmeli sorular

\begin{tabular}{lll}
\hline Soru Numarası & $\begin{array}{l}\text { Ayırt Edicilik } \\
\text { İndeksi }\end{array}$ & Point Biserial \\
\hline 1 & 0.29 & 0.34 \\
2 & 0.52 & 0.48 \\
3 & 0.38 & 0.34 \\
4 & 0.23 & 0.31 \\
5 & 0.21 & 0.26 \\
6 & 0.02 & 0.11 \\
7 & 0.20 & 0.29 \\
8 & 0.25 & 0.29 \\
9 & 0.34 & 0.37 \\
10 & 0.37 & 0.40 \\
\hline
\end{tabular}

Maddelere ait madde toplam test korelasyon katsayıları maddelerin ölçeğin bütünü ile ölçülmek istenen özelliği iyi ölçebilen maddeler olup olmadıklarını gösterir (Şahin \& Gülleroğlu, 2013). Korelasyon katsayısının, mutlak değer olarak 0,70-1,00 arasında olması yüksek, 0,30- 0,70 arasında olması orta, 0,00-0,30 arasında olması düşük düzeyde bir ilişki olarak tanımlanabilir (Öztürk, Çakmak , Akgün, Karadeniz \& Demirel, 2011). Tablo 3' te açık uçlu sorular için madde puanı-toplam puan korelasyon ilişkisine bakılmıştır. 
Tablo 3. Hazır bulunuşluk testi pilot çalışma analizi-açık uçlu sorular

\begin{tabular}{lll}
\hline Sorular & Pearson Korelasyon & $\mathbf{p}$ \\
\hline 11 & 0.384 & 0.001 \\
12 & 0.376 & 0.001 \\
13 & 0.402 & 0.000 \\
14 & 0.313 & 0.005 \\
15 & 0.212 & 0.063 \\
\hline
\end{tabular}

Testteki bir soruya alt ve üst grupta doğru cevap veren öğrencilerin puanları arasındaki fark ne kadar artarsa sorunun ayıt ediciliği de o kadar artar. Ayırt ediciliği yüksek maddeler testin güvenirliğini ve geçerliğini arttırır. Yapılan bu analiz ve incelemeler doğrultusunda ayırt edicilik indeksi ve Point Biserial değeri 0,30 dan düşük olduğundan 6 ve 7 numaralı sorular ve korelasyon katsayısı 0,30 dan düşük olan 15 numaralı sorular çıkarılmış ve ayırt edicilik indeksi ve Point Biserial değeri 0,20 ile 0,30 arasında bulunan 8 numaralı soruda düzenlemeye gidilmiştir.

Araştırma çalışması öncesinde Hazır Bulunuşluk Testi (HBT) ‘nin pilot çalışmasında Cronbach alfa güvenirlik katsayısı 0,551 düzeyinde bulunmuştur. Son şekli verilen ve araştırmada uygulanan HBT için ise Cronbach alfa güvenirlik katsayısı 0,585 olarak belirlenmiştir. Şencan (2005), testin güvenirliği için Cronbach alfa katsayısının ön deneme araştırmaları için 0,60, bilimsel içerik araştırmaları için 0,70 olmasının gerekli olduğunu belirtmiştir. Dolayısıyla HBT güvenirlik katsayısı, 0,60 barajını yaklaşık olarak sağlamakta ve bu durumda güvenirliği olumsuz etkileyecek bir problem görülmemektedir.

Fonksiyon Başarı Testi (FBT)

Uygulama sonunda deney grubu ve kontrol grubunun fonksiyon konusundaki başarıları arasında anlamlı bir farklılık oluşup oluşmadığını ölçmek için çoktan seçmeli ve açı uçlu sorular olmak üzere toplam 18 sorudan oluşan ve MEB, 9. sınıf matematik öğretim programındaki fonksiyon konusunun kazanımlarına uygun olacak şekilde bir Fonksiyon Başarı Testi (FBT) araştırmacı tarafından hazırlanmıştır. FBT soruları 4 uzman tarafından incelenerek dil, kapsam ve psikometrik özellikleri açılarından değerlendirilmiştir. Bu değerlendirmeler ışığında FBT oluşturulup deneysel çalışmadan önce Ankara ili Etimesgut ilçesindeki bir Anadolu lisesinde öğretim gören 9. sınıf öğrencilerinden 60 kişi üzerinde pilot çalışması yapılmıştır. Yapılan uygulama sonrasında testin psikometrik özelliklerini belirlemek için madde güçlüğü, madde ayırt ediciliği ve korelasyon analizleri yapılarak testin madde analizi gerçekleştirilmiştir. Analizlerde Iteman ve SPSS programları kullanılmıştır. Tablo $4^{\prime}$ te çoktan seçmeli sorular için uygulanan Iteman analiz sonuçları 
verilmiştir. Ayrıca açık uçlu sorular için madde puanı-toplam puan korelasyon ilişkisine bakılmıştır. Tablo $5^{\prime}$ te ise açık uçlu sorular için yapılan korelasyon analiz sonuçları verilmiştir.

Tablo 4. Fonksiyon başarı testi pilot çalışma analizi-çoktan seçmeli sorular

\begin{tabular}{lll}
\hline Sorular & Ayırt Edicilik İndeksi & Point Biserial \\
\hline 1 & 0.26 & 0.39 \\
2 & 0.47 & 0.46 \\
3 & 0.41 & 0.39 \\
4 & 0.32 & 0.31 \\
5 & 0.19 & 0.23 \\
6 & 0.34 & 0.37 \\
7 & 0.51 & 0.39 \\
8 & 0.28 & 0.34 \\
\hline
\end{tabular}

Tablo 5. Fonksiyon başarı testi pilot çalışma analizi-açık uçlu sorular

\begin{tabular}{lll}
\hline Sorular & Pearson Korelasyon & $\mathbf{p}$ \\
\hline 9 & 0.180 & 0.168 \\
10 & 0.481 & 0.000 \\
11 & 0.278 & 0.032 \\
12 & 0.526 & 0.000 \\
13 & 0.353 & 0.006 \\
14 & 0.378 & 0.03 \\
15 & 0.494 & 0.000 \\
16 & 0.440 & 0.000 \\
17 & 0.423 & 0.001 \\
18 & 0.462 & 0.000 \\
\hline
\end{tabular}

Yapılan bu analiz ve incelemeler doğrultusunda 5 ve 8 numaralı sorular ayırt edicilik indeksi ve Point Biserial değeri 0,30 dan düşük olduğundan, 9 numaralı soru ise Pearson korelasyon katsayısı 0,30 dan düşük olduğundan testten çıkarılmış ve ayırt edicilik indeksi 0,30 sinırına yakın olan 1 numaralı ve Pearson korelasyon katsayısı 0,30 sınırına yakın bulunan 11 numaralı sorularda da düzenlemeye gidilmiştir. Pilot çalışma sonrasında son şekli verilen ve 15 sorudan oluşan Fonksiyon Başarı Testi uygulama sonrasında deney ve kontrol grubu öğrencilerine uygulanmıştır.

FBT için kapsam geçerliği çalışması çerçevesinde soruların Bilginin Derinliği Seviyeleri (BDS) modeline göre bilişsel seviyelere ve konulara göre dağılımı incelenmiştir. Bilginin Derinliği Seviyeleri (BDS) modeli, öğrenenlerin bilişsel gerekliliklerini karşılayacak eğitim materyalleri üzerine çalışmaları analiz etmek ve standartlar ile değerlendirme arasındaki tutarlılığı incelemek üzere Webb (1999) tarafından geliştirilen bir çerçevedir. 
Ayrıca bu model bir taksonomiden ziyade bir sinıflamadır. Bu sinıflama hatırlama ve yeniden üretme, beceri ve kavramlar, stratejik düşünme ve geniş düşünme olmak üzere dört seviyeden oluşmaktadır. Fonksiyon Başarı Testinin kapsam geçerliliğini incelemek üzere BDS bilişsel düzeylerine ve konu başlıklarına göre soru dağılımları güvenirlik çalışması için iki uzmana inceletilerek uyuşma yüzdesi hesaplanmıştır. Uyuşma yüzdesinin hesaplanmasının ve elde edilen sonuçların anlaşılmasının kolaylığı, bu yöntemin tercih edilme sebebi olmuştur (Goodwin, 2001). Puanlayıcılar arası değerlendirme sonuçlarının güvenilir sayılabilmesi için uyuşma yüzdesinin \%75'in üzerinde olması gerekmektedir. (Şencan, 2005). Bu tablodaki dağılımın uyuşma yüzdesi \%77 olarak hesaplanmıştır. Böylelikle FBT sorularının konulara ve bilişsel düzeylere göre dağılımının dengeli olduğu görülmüştür.

Araştırma için hazırlanan Fonksiyon Başarı Testinin Cronbach alfa güvenirlik katsayısı pilot çalışmada 0,779 olarak tespit edilmiştir. Çalışma sonunda uygulanan FBT'nin son şekli için Cronbach alfa güvenirlik katsayısı ise 0,817 olarak hesaplanmıştır.

Verilerin Toplanması ve Analizi

Öğrencilerin uygulama öncesinde matematik dersi akademik başarı seviyeleri Hazır Bulunuşluk Testiyle, uygulama sonunda iki grubun fonksiyon konusundaki akademik başarıları Fonksiyon Başarı Testiyle nicel olarak ölçülmüştür. Bu çalışmada veri analizi SPSS programı ile yapılmıştır. Testlerin ölçüm geçerliği yanıt süreçleri üzerine temellenmiş kanıtlar kullanılarak yapılmıştır. Araştırmanın başlangıcında uygulanan Matematik Hazır Bulunuşluk Testinin analizi bağımsız örneklemler t-testi ile yapılmış, çalışmanın sonunda uygulanan Fonksiyon Başarı Testinin analizi bağımsız örneklem t-testi ile yapılmıştır.

\section{Bulgular}

Çalışmada “Teknoloji Destekli Problem Çözmeye Dayalı Günlük Hayat Uygulamalarının kullanıldığı deney grubu öğrencileri ile geleneksel öğretim yapılan kontrol grubu öğrencilerinin fonksiyon konusundaki başarıları arasında anlamlı bir farklılık var mıdır?" problemini sonuca ulaştırmak için aşağıda yer alan analizler gerçekleştirilmiştir.

\section{Hazır Bulunuşluk Testi Analizleri}

Araştırma öncesinde deney ve kontrol gruplarına uygulanan bu testin sonuçlarının normal dağılıma sahip olup olmadığı incelenmiştir. Dağılımın normal olduğu görüldüğünden bu test deney ve kontrol gruplarına uygulanarak sonuçları bağımsız gruplar için $\mathrm{t}$ testi ile analiz edilmiştir. 
Kontrol grubunun HBT puan ortalaması 43,75, deney grubunun puan ortalaması 36,42'ye nispeten daha yüksek görünse de iki grubun hazır bulunuşluk testi puanları arasında $t$ testi sonucunda $p>0,05$ olduğundan deney grubu öğrencileri ile kontrol grubu öğrencilerinin matematik dersi akademik başarıları arasında çalışma öncesinde anlamlı bir farklılık olmadığı belirlenmiştir. Dolayısıyla deney ve kontrol gruplarının matematik dersi hazır bulunuşluk düzeylerinin istatistiksel olarak birbirine denk olduğu tespit edilmiştir. Deney ve kontrol grubu öğrencilerinin hazır bulunuşluk testi puanlarının betimsel istatistikleri Tablo $6^{\prime}$ da ve deney ve kontrol grubu öğrencilerinin HBT puanlarını karşılaştırmak üzere yapılan $\mathrm{t}$ testi sonuçları da Tablo 7' de gösterilmiştir.

Tablo 6. Hazır bulunuşluk testi betimsel istatistikleri

\begin{tabular}{llllll}
\hline Gruplar & $\mathrm{n}$ & $\begin{array}{l}\text { Minimum } \\
\text { Puan }\end{array}$ & $\begin{array}{l}\text { Maksimum } \\
\text { Puan }\end{array}$ & Ortalama & $\begin{array}{l}\text { Standart } \\
\text { Sapma }\end{array}$ \\
\hline Deney & 24 & 16 & 93 & 36,42 & 16,95 \\
Kontrol & 20 & 17 & 84 & 43,75 & 18,99 \\
\hline
\end{tabular}

Tablo 7. Hazır bulunuşluk testi bağımsız örneklem $t$ testi istatistikleri

\begin{tabular}{llrrrrc}
\hline Gruplar & $\mathrm{n}$ & $\bar{x}$ & $\mathrm{~S}$ & $\mathrm{sd}$ & $\mathrm{t}$ & $\mathrm{P}$ \\
\hline Deney & 24 & 36,42 & 16,95 & 42 & $-1,353$ & 0,183 \\
Kontrol & 20 & 43,75 & 18,99 & & & \\
\hline
\end{tabular}

\section{Fonksiyon Başarı Testi (FBT) Analizleri}

$\mathrm{Bu}$ çalışmada son test olarak uygulanan $\mathrm{FBT}^{\prime}$ nin sonuçlarının normal dağılıma sahip olup olmadığı incelenmiştir. Aşağıdaki Tablo $8^{\prime}$ de yer alan sonuçlar dağılımın normal olduğunu göstermektedir. Analiz sonuçları gerekli varsayımları sağladığından TPU sonrasında FBT deney ve kontrol gruplarına uygulanmış ve bağımsız gruplar için $\mathrm{t}$ testi kullanılarak analiz edilmiştir.

Tablo 8. Normal dağılım analizi istatistikleri

\begin{tabular}{llll}
\hline Gruplar & \multicolumn{3}{c}{ Shapiro-Wilk } \\
\hline \multirow{3}{*}{ Deney } & Statistic & $\mathrm{df}$ & Sig. \\
\cline { 2 - 4 } Kontrol & 0,970 & 24 & 0,670 \\
& 0,856 & 20 & 0,564 \\
\hline
\end{tabular}

Deney ve kontrol grubu öğrencilerinin FBT puanlarının betimsel istatistikleri Tablo 9' da ve iki grubun FBT puanlarını karşılaştırmak üzere yapılan t testi sonuçları da Tablo 10' da gösterilmiştir. İki grubun FBT puanları arasında $\mathrm{t}$ testi sonucunda $\mathrm{p}<0,05$ olduğundan anlamlı bir farklılık görülmüştür. Bu sonuç TPU yapılan deney grubu öğrencileri ile geleneksel öğretim yapılan kontrol grubu öğrencilerinin matematik dersi akademik 
başarıları arasında deney grubu lehine anlamlı bir farklılık ortaya çıkmış olduğunu göstermiştir. Bu bulguların önemini belirlemenin kabul gören bir yolu Etki Ölçüsünü (Eta square) hesaplamaktır. Bu analiz bağımlı değişkenin ortalamalar farkı (bağımsız değişken) üzerindeki etki büyüklügünü göstermektedir. FBT puanları analizinde Etasquare 0,14 bulunmuştur. Bu düzey Cohen (1988) kriterlerine göre etkinin büyük olduğunu göstermiştir.

Tablo 9. Fonksiyon başarı testi betimsel istatistikleri

\begin{tabular}{llllll}
\hline Gruplar & $\mathrm{n}$ & $\begin{array}{l}\text { Minimum } \\
\text { Puan }\end{array}$ & $\begin{array}{l}\text { Maksimum } \\
\text { Puan }\end{array}$ & Ortalama & $\begin{array}{l}\text { Standart } \\
\text { Sapma }\end{array}$ \\
\hline Deney & 24 & 14 & 77 & 51,08 & 13,54 \\
Kontrol & 20 & 2 & 79 & 34,30 & 26,08 \\
\hline
\end{tabular}

Tablo 10. Fonksiyon başarı testi bağımsız örneklem $\mathrm{t}$ testi istatistikleri

\begin{tabular}{llcccccc}
\hline Gruplar & $\mathrm{n}$ & $\bar{x}$ & $\mathrm{~S}$ & $\mathrm{sd}$ & $\mathrm{t}$ & $\mathrm{p}$ & EtaSquare \\
\hline Deney & 24 & 51,08 & 13,54 & 27 & 2,60 & 0,015 & 0,14 \\
Kontrol & 20 & 34,30 & 26,08 & & & & \\
\hline
\end{tabular}

\section{Tartışma ve Sonuç}

Deney ve kontrol gruplarına çalışma öncesinde uygulanan Hazır Bulunuşluk Testi puanlarının analizi için yapılan bağımsız örneklemler için $t$ testi sonucunda $p>0,05$ bulunduğundan anlamlı bir farklılık olmadığı ve grupların matematik dersi akademik başarı seviyeleri açısından denk olduğu görülmüştür. Çalışma sonunda uygulanan Fonksiyon Başarı Testinin sonuçları deney grubunun puan ortalamasının, kontrol grubunun puan ortalamasından daha yüksek olduğunu göstermiştir. İki grubun FBT puanları arasında t testi sonucunda $\mathrm{p}<0,05$ bulunduğundan TPU ile matematik dersinin işlendiği deney grubu öğrencileri ile geleneksel öğretim yapılan kontrol grubu öğrencilerinin matematik dersi akademik başarıları arasında deney grubu lehine anlamlı bir farklılık olduğu belirlenmiştir. Yapılan bağımsız örneklemler için $t$ testi ve etki büyüklüğü analizleri sonucunda TPU' nun deney grubu öğrencilerinin akademik başarıları üzerinde istatistiksel olarak anlamlı ve büyük etkisi olduğu saptanmıştır. Bu sonuç TPU 'nun öğrencilerin matematik başarısını artırmada büyük ölçüde etkili olduğunu göstermiştir.

TPU 'nun matematik başarısını artırmada etkili olmasının altında yatan sebeplerden birisi teknolojinin matematik öğretiminde kullanılması olabilir. Çünkü teknolojinin sunduğu görsellik öğrencileri motive eder, ilgilerini çeker ve matematiksel kavramların mantığını anlamaya yardımcı olur. Ayrıca teknoloji işlemlerle zaman kaybetmeye engel olup öğrencilerin üst düzey düşünme becerilerini geliştirmelerine imkân sağlayarak daha iyi 
öğrenmelerini sağlamaktadır. Nitekim Sheehan ve Nillas (2010) teknolojinin kavramları görselleştirerek öğrencilerin anlamalarını kolaylaştırdığını, farklı matematiksel gösterimler arasında ilişki kurmalarına yardımcı olduğunu belirlemişlerdir. Bunun yanı sıra, teknolojinin matematik başarısını artırmada etkili olduğu yapılan birçok akademik araştırma tarafından teyit edilmiştir. Örneğin, Simonsen ve Dick (1997), Hannafin (2001), Ellingon (2003) ve Serhan (2000) yaptıkları araştırmaların sonucunda teknoloji kullanımının öğrencilerin matematik dersi başarılarını, derse katılımlarını, konuyu içselleştirerek kavramalarını artırdığını ve matematiğin gerçek dünya ile ilişkilerini görmelerine yardımcı olduğunu belirlemişlerdir. Bunların yanı sıra, Funkhouser (2002) dinamik matematik yazılımı kullanan grubun başarısının düz anlatım kullanan gruptan anlamlı biçimde daha yüksek olduğunu belirlemiştir. Buna paralel olarak Almeqdadi (2005) 9. sinıflar üzerinde yaptı̆̆1 benzer bir çalışmanın sonucunda dinamik matematik yazılımı kullanımının öğrencilerin matematik dersi başarılarını anlamlı biçimde artırdığını belirlemiştir. Ayrıca, Zengin, Furkan ve Kutluca (2012) dinamik matematik yazılımı GeoGebra'nın trigonometri öğretimindeki öğrenci başarısı üzerindeki etkilerini incelemek üzere yaptıkları çalışmanın sonuçları, deney ve kontrol gruplarının trigonometri konusundaki başarıları arasında GeoGebra ile öğretim gören deney grubu lehine anlamlı bir farklılık olduğunu göstermiştir.

TPU uygulaması sonucu öğrencilerin matematik başarılarının artmasının bir diğer sebebi ise öğrencilerin bu uygulamalarla derse aktif katılımlarının sağlanması olabilir. Zira TPU uygulamaları, öğrenciler için daha ilginç ve katılımcı olmakla kalmaz, bunun yanında konunun daha iyi anlaşılmasını sağlar. Çünkü TPU ile öğrenciler bilgiyi kendileri keşfederler ve bunun ardından çalışmayı tamamlamak için bilgiyi ve yeteneklerini aktif olarak kullanırlar. Uysal (1996) tarafından yapılan araştırmanın sonucunda, öğrenme sürecine etkin öğrenci katılımının başarıyı artırdığı ve öğrencinin öğrenme sürecine etkin katılım düzeyi ile başarısı arasında olumlu bir ilişki olduğu gözlemlenmiştir.

$\mathrm{Bu}$ çalışmada deney grubunun başarısının bir sebebi de günlük hayat uygulamalarıyla öğrencilerin dersi benimsemelerinin ve derse motive olmalarının sağlanması olabilir. Çünkü öğrencilerin içinde yaşadıkları fiziksel dünyayı anlamalarını sağlayacak günlük hayata dair etkinlikler uygulamak, öğrencilere düşünme becerilerini daha yüksek seviyelere çıkarma ve bilgilerini zenginleştirme imkânı sunar. Ayrıca matematiğin mantıklı ve anlamlı bir alan olduğunu anlamaları, öğrencilerin akıl yürütme ve muhakeme becerilerini geliştirmelerine yardımcı olmaktadır. Öğrenciler, sürekli olarak bir konuyu 
neden çalışmaları gerektiğini ya da bunun onlara ne gibi bir yarar getireceğini sormaktadırlar. Probleme Dayalı Öğrenme (PDÖ), bu soruları öğrenmeyi gerçek yaşamın içine yerleştirerek yanıtlamaktadır (Delisle, 1997). Öğrencilerin PDÖ yöntemi ile problemi çözdükleri zaman "Bunu neden bilmemiz gerekiyor?" sorusu bilinen gerçek dünya sorularından olduğundan daha sorulmadan cevaplanmış olur (Hill, 2012). Öğrenciler çalıştıkları konularla, problemlerle kendi yaşamları arasında bağlantılar gördüklerinde anlamak ve hatırlamak için daha büyük bir çaba göstermektedirler. Çünkü matematiğin önemini anlayan bir öğrencinin öğrenme isteği artmaktadır.

PDÖ yönteminin akademik başarıyı artırdığını gösteren birçok çalışma bulunmaktadır. Örneğin, Özgen (2007) yaptığı çalışmanın sonucunda matematik eğitiminde PDÖ yönteminin, öğrencilerin akademik başarı düzeylerini arttırdı̆̆ı, matematik dersine yönelik tutum düzeylerini yükselttiği ve hatırda tutma düzeylerini geliştirdiği sonuçlarına varmıştır. Bununla birlikte, Uslu (2006) yaptığı araştırmanın sonucunda matematik öğretiminde probleme dayalı öğrenme yönteminin öğrencinin tutumunu, başarısını ve bilginin kalıcılık düzeyini geleneksel yönteme göre anlamlı derecede ve olumlu yönde etkilediğini belirlemiştir. Ayrıca Botty, Jaidin, Li, Shahrill ve Chong (2016) yaptıkları çalışma sonucunda PDÖ'nün öğrencilerin matematiği öğrenmeleri açısından pozitif yönde faydalı olduğunu belirlemişlerdir. Bunların yanı sıra, Altıparmak ve Akın (2017) ilköğretim öğrencilerinin üzerinde PDÖ’nün akademik başarıya etkisini inceledikleri çalışmanın sonucunda PDÖ uygulanan grubun başarısının diğer gruptan anlamlı biçimde yüksek olduğunu tespit etmişlerdir.

\section{Öneriler}

Araştırmadan elde edilen bulgular ve sonuçlar temel alınarak şu öneriler verilebilir: Teknoloji destekli problem çözmeye dayalı günlük hayat uygulamalarının, genel matematik dersinin "Fonksiyon" ünitesinde öğrencilerin akademik başarılarını artırma konusunda etkili olduğu sonucuna varıldığından, bu uygulama genel matematiğin farklı ünitelerinde veya matematiğin diğer alanlarında yapılabilir.

Ayrıca, bu çalışma sadece 9.sınıf öğrencileri üzerinde uygulandı̆̆ından farklı seviyedeki sınıflar üzerinde de uygulanarak başarı üzerindeki etkileri karşılaştırılabilir. Bununla birlikte, TPU' nun başarı üzerindeki etkisinin altında yatan sebepler nitel bir çalışmayla derinlemesine incelenerek belirlenebilir. Bu sayede TPU' nun başarı üzerindeki etkisi daha iyi anlaşılabilir. 
Bilgilendirme

Bu çalışma, Başkent Üniversitesi'nden Prof.Dr. Şeref Mirasyedioğlu'nun danışmanlığında Yücel Çetin'in doktora tezinin bir parçasından oluşmaktadır.

\section{Kaynaklar}

Ali, R., Hukamdad, D. Akhter, A., \& Khan, A. (2010). Effect of using problem solving method in teaching mathematics on the achievement of mathematics students. Asian Social Science, 6(2), 67-72.

Almeqdadi, F. (2005). The effect of using the geometer's sketchpad (gsp) on jordanian students' understanding some geometrical concepts. International Journal for Mathematics Teaching and Learning http://www.cimt.plymouth.ac.uk/journal/almeqdadi.pdf adresinden alınmıştır.

Altıparmak, K. \& Akın, P. (2017). Probleme dayalı öğrenme yönteminin etkililiği üzerine deneysel bir çalışma. Adıyaman Üniversitesi Sosyal Bilimler Enstitüsü Dergisi, 9(26), 459492.

Aydın, M., Laçin, S. \& Keskin, İ. (2018). Ortaöğretim matematik dersi öğretim programının uygulanmasına yönelik öğretmen görüşleri. International e-Journal of Educational Studies,2(3), 1-11.

Baysal, N. (2003). Illköğretim sosyal bilgiler dersinde öğretmen tutumlarının problem çözmeye dayalı ögrrenmeye etkisi. Doktora Tezi, Marmara Üniversitesi Eğitim Bilimleri Enstitüsü, İstanbul.

Botty, R.H.Jaidin, J.H., Li, H. , Shahrill, M. \& Chong, S.F. (2016). The implementation of problem-based learning in a year 9 mathematics classroom: A Study in Bruneidarussalam. International Researchs in Education, 4(2), 34-47.

Cansız, Ş., Küçük, B. \& İşleyen, T. (2011). Identifying the secondary school students' misconceptions about functions. Procedia Social and Behavioral Sciences, 15, 3837-3842.

Cohen, J. (1988). Statistical power analysis for the behavioral sciences (2nd ed.). Hillsdale, NJ: Lawrence Earlbaum Associates.

Delisle, R. (1997). How to use problem-based learning in the classroom. Alexandria, VA: The Association for Supervision and Curriculum Development.

Ellington, A. J. (2003). A meta-analysis of the effects of calculators on students' achievement and attitude levels in precollege mathematics classes. Journal for Research in Mathematics Education, 34 (5), 433-463.

Fies, C. (2007). Research summary: Digital technologies in mathematics and science education.http://ww.nmsa.org/ResearchSummaries/DigitalTechnology/tabid/1486/De fault.aspx adresinden alınmıştır.

Funkhouser, C. (2002). The effects of computer-augmented geometry instruction on student performance and attitudes.Journal of Research on Technology in Education,35(2), 163-175.

Gay, L.R. \& Airasian, P. (2000). Educational research. New Jersey: Van Hoffman. 
Goodwin, L. D. (2001). Interrater Agreement and Reliability. Measurement in Physical education and Exercise Science, 5 (1), 13-14.

Günhan, B. \& Başer, N. (2009). Probleme dayalı öğrenmenin öğrencilerin eleştirel düşünme becerilerine etkisi. Türk Ĕ̆itim Bilimleri Dergisi, 7 (2), 451-482.

Haladayna, T.M. (1997). Writing test items to evaluate higher order thinking. Needham Heights, Aviacom Company.

Hannafin, R. D., Burruss, J. D. ve Little, C. (2001). Learning with dynamic geometry programs: Perspectives of teachers and learners. Journal of Educational Research, 94(3), $132-44$.

Hawson, G. (1994). Matematik eğitimine tarihsel bir bakış (T. Tanyol, Çev.), Bilim Tarihi, 27(3), 22-30.

Hill, J. (2012) Problem-based learning. Yüksek Lisans Tezi, Moravian College Bethlehem, Pennsylvania.

Hmelo-Silver, C.E. (2004). Problem-based leaming: What and how do students leam? Educational Psychology Review, 16(3). 235-266.

Hoyles, C. \& Noss, R. (1992). A pedagogy for mathematical microworlds. Educational Studies in Mathematics, 23(1), 31-57.

Kabael, U. T. (2010). Fonksiyon kavramı: Tarihi gelişimi, öğrenilme süreci, öğrenci yanılgıları ve öğretim stratejileri. Tübav Bilim Dergisi, 3(1), 128-136.

Kalaycı, Ş. (2010). SPSS uygulamalı çok değişkenli istatistik teknikleri. Ankara: Pegem Akademi.

Kocakülah, A. (2006). Geleneksel öğretimin ilk, orta ve yükseköğretim öğrencilerinin görüntü oluşumu ve renklere ilişkin kavramsal anlamalarma etkisi. Doktora Tezi, Balıkesir Üniversitesi, Fen Bilimleri Enstitüsü, Balıkesir.

Kutluca, T. \& Baki, A. (2013). İkinci dereceden fonksiyonlar konusunda geliştirilen çalışma yaprakları hakkında öğrenci görüşlerinin değerlendirilmesi. Hacettepe Üniversitesi Ĕ̆itim Fakültesi Dergisi 28(3), 319-331.

Leinhardt, G., Zaslavsky, O. \& Stein, M. K. (1990). Functions, graphs, and graphing: tasks, learning, and teaching. Review of Educational Research, 60(1), 1-64.

Malahlela, V. (2017) Using errors and misconceptions as a resource to teach functions to grade 11 learners. Yüksek Lisans Tezi, University of the Witwaters, School of Education and the Faculty of Science, Johannesburg.

Milli Eğitim Bakanlı̆̆ [MEB] (2018). Ortaöğretim matematik dersi öğretim programı ve kılavuzu. MEB Talim, Terbiye Kurulu Başkanlığı - Ankara: Devlet Kitapları Müdürlüğü.

National Council of Teachers of Mathematics [NCTM] (2001). Curriculum and evaluation standards for school mathematics. Reston VA: The Council.

National Council of Teachers of Mathematics [NCTM] (2013). Curriculum and evaluation standards for school mathematics. Reston VA: The Council.

Özgen, K. (2007). Matematik dersinde probleme dayalı öğrenme ürünlerine etkileri. Yüksek Lisans Tezi, Dicle Üniversitesi Fen Bilimleri Enstitüsü, Diyarbakır. 
Öztürk, Ş., Çakmak ,E.K., Akgün, Ö.E., Karadeniz ,Ş. \& Demirel, F. (2011 ). Bilimsel araştırma yöntemleri, Ankara: Pegem Akademi.

Serhan, D. (2000). The effect of graphing calculators use on students' understanding of the derivative at a point. Doktora Tezi, Arizona State University, Arizona.

Soylu, Y. (2009). Sınıf öğretmen adaylarının matematik derslerinde öğretim yöntem ve teknikleri kullanabilme konusundaki yeterlilikleri üzerine bir çalışma. Mersin Üniversitesi Ĕ̆itim Fakültesi Dergisi, 5(1), 1-16.

Steedman, P.H. (1991). There is no more safety in numbers: A new conception of mathematics teaching. E. Von Glasersfeld: Radical Constructivism in Mathematics Education. Netherlands: Kluwer Academic.

Simonsen, L., \& Dick, T. (1997). Teachers' perceptions of the impact of graphing calculators in the mathematics classroom. Journal of Computer in Mathematics and Science Teaching, $16(2-3), 239-268$.

Şahin, D. B. \& Gülleroğlu H. D. (2013). Likert tipi ölçeklere madde seçmede kullanılan farklı madde analizi teknikleri ile oluşturulan ölçeklerin psikometrik özelliklerinin incelenmesi. Asya Öğretim Dergisi, 1(2), 18-28.

Şencan, H. (2005). Sosyal ve davranışsal ölçümlerde güvenirlik ve geçerlilik. Ankara: Seçkin Yayıncilik.

Sheehan, M. \& Nillas, A.L. (2010). Technology integration in secondary mathematics classrooms: Effect on students' understanding. Journal of Technology Integration in the Classroom, 2(3), 67-83.

Torp, L. \& Sage, S. (2002). Problems as possibilities: problem-based learning for K-12 education. Virginia, USA: Alexandria, VA: Association for Supervision and Curriculum Development.

Umay, A. (1996). Matematik eğitimi ve ölçülmesi. Hacettepe Üniversitesi Eğitim Fakültesi Dergisi, 12(21), 145-149.

Uslu, G. (2006). Matematik eğitim ortaöğretim matematik dersinde probleme dayalı öğrenmenin öğrencilerin derse ilişkin tutumlarına, akademik başarılarına ve kalıcılık düzeylerine etkisi. Yüksek Lisans Tezi, Balıkesir Üniversitesi Fen Bilimleri Enstitüsü, Balıkesir.

Uysal, Ö.F. (1996). Öğrenme sürecinde etkin öğrenci katılımının öğrenme sonuçlarına etkisi. Doktora Tezi, Dokuz Eylül Üniversitesi Sosyal Bilimler Enstitüsü, İzmir.

Usta, N. \& Mirasyedioğlu, Ş. (2017). Problem tabanlı öğrenme yaklaşımı ile matematik öğretiminin 7. sınıf öğrencilerinin matematik başarısına ve özyeterliğine etkisi. Kastamonu Ĕ̆itim Dergisi, 25(6), 2263-2282.

Webb, N. (1999). Research monograph No. 18: Alignment of science and mathematics standards and assessments in four states. Washington, D.C.: CCSSO.

Zengin, Y. \& Tatar, E. (2015) The teaching of polar coordinates with dynamic mathematics software, International Journal of Mathematical Education in Science and Technology, 46(1), 127-139.

Zengin, Y., Furkan, H. \& Kutluca, T. (2012). The effect of dynamic mathematics software geogebra on student achievement in teaching of trigonometry. Social and Behavioral Sciences 31, 183-187. 


\section{EK. Kontrol ve Deney Grubu Etkinlik Örnekleri}

Kontrol Grubu Ders İşleyiş Örneği

Bir fonksiyonun değeri daima sabit bir oranda artıyor ya da azalıyor ise bu fonksiyona doğrusal fonksiyon denir. Doğrusal fonksiyon $f(x)=a x+b$ biçiminde gösterilir ve grafiği doğrusal biçimdedir.

Örnek:

$h(x)$ in doğrusal bir fonksiyon olduğu biliniyor. $h(1)=7, h(3)=11$ değerleri verildiğine göre, $h(7)$ değerini bulunuz.

Örnek:

Aşağıda iki noktası verilen doğrusal fonksiyonun kuralını belirleyiniz.

$(2,5)$ ve $(6,13)$

Deney Grubu Ders İşleniş Örnek Etkinliği

Etkinlik 5: Doğrusal Fonksiyon (Cep Telefonu) Etkinliği

Yeni bir cep telefonu alan Zeynep, saat 10.00'da bataryayı tamamen şarj ettikten sonra günün farklı saatlerinde bataryanın kalan şarj yüzdesini ve saatini aşağıdaki tabloya kaydediyor.

\begin{tabular}{|l|l|}
\hline Saat & Batarya Şarj Yüzdesi \\
\hline 12.00 & $\% 96$ \\
\hline 15.00 & $\% 90$ \\
\hline 19.00 & $\% 82$ \\
\hline 24.00 & $\% 72$ \\
\hline
\end{tabular}

1. Bu tabloyu Geogebra programında hesap çizelgesi görünümünde yerleştiriniz.

2. Hesap çizelgesini tarayarak verilerin grafiğini sağa tıklayıp oluşturunuz. Nasıl bir grafik ortaya çıktığını ve bu grafiğin ne tür bir fonksiyon belirttiğini ifade ediniz.

3. İki değişkenli regresyon analizini tıklayıp fonksiyonun grafiğini ve formülünü belirleyiniz. Ne şekilde bir grafik ortaya çıktığını ve sebebini açıklayınız.

4. Zeynep bataryayı tamamen şarj ettikten 20 saat sonra bataryanın şarj yüzdesinin kaça düşeceğini belirlemek için Geogebra' da regresyon analizi bölümünde x değerini 20 olarak girip enter tuşuna basınız. Bulduğunuz y değerini kaydediniz.

5. Bu verileri kullanarak bataryanın şarjının tamamen kaç saatte tükeneceğini belirleyiniz. 